\title{
Interspecific rearing and acceptance of queens between Apis cerana Fabricius, 1793 and Apis koschevnikovi Buttel-Reepen, 1906
}

\author{
N Koeniger 1, G Koeniger 1, S Tingek 2, A Kelitu 2 \\ 1 Institut für Bienenkunde (Polytechnische Gesellschaft), Fachbereich Biologie \\ der JW Goethe-Universität Frankfurt aM, Karl-von-Frisch-Weg 2, 61440 Oberursel, Germany; \\ 2 Agricultural Research Station, Lagud Seberang PO Box 197, 89908 Tenom, Sabah, Malaysia
}

(Received 19 July 1996; accepted 4 October 1996)

Summary - Artificial queen cells with grafted young worker larvae of Apis cerana and Apis koschevnikovi were simultaneously introduced into queenless colonies of either $A$ cerana and $A$ koschevnikovi. All colonies preferred to rear conspecific larvae. The degree of this larval preference was different: A cerana colonies were more selective than $A$ koschevnikovi colonies against alien larvae. In contrast, the $A$ koschevnikovi colonies destroyed most of the introduced mature $A$ cerana queen cells and killed all the queens that were able to emerge. A long term acceptance of alien queens occurred in A cerana colonies. The A koschevnikovi queens performed successful mating flights from $A$ cerana colonies and the time of mating flights of these queens did not differ from $A$ koschevnikovi queens flying from conspecific colonies. The mated $A$ koschevnikovi queens laid eggs and the emerged bees were successfully reared by the $A$ cerana worker bees. The $A$ cerana host colonies were gradually transformed into $A$ koschevnikovi colonies.

Apis cerana / Apis koschevnikovi / queen / interspecific relation / reproduction

\section{INTRODUCTION}

The cavity-nesting honey bee species Apis cerana Fabricius, 1793 and Apis koschevnikovi Buttel-Reepen, 1906 share several common morphological and behavioral characters such as prolonged radial vein of the hind wing, pore in the capping of the drone brood cell and fanning position with the head towards the colony entrance. These characters are not found in the West- ern Apis mellifera L (Ruttner, 1988; Tingek et al, 1988). Further, multivariate morphometric analysis resulted in phenotypic similarities between both Asian species that confirmed the taxonomic status of $A$ cerana and $A$ koschevnikovi as closely related, distinct species (Ruttner et al, 1989; Rinderer et al, 1989).

Colonies of both species commonly occur in the region of Tenom (Sabah, Malaysia) which offer a favorable basis for compara- 
ble experimental research. Recently, the exchange of drone brood between colonies of $A$ cerana and $A$ koschevnikovi resulted in mixed populations of drones from both honey bee species. These drones flew at their species-specific mating time regardless of whether they were in conspecific or the other species' colonies (Koeniger et al, 1994).

The successful reciprocal interspecific acceptance of drone brood and drones led us to the question of whether or not experimentally exchanged queen larvae and queens of $A$ cerana and $A$ koschevnikovi were reared and accepted by colonies of the other species.

\section{MATERIAL AND METHODS}

The experiments were carried out in the apiaries of Agricultural Research Station near Tenom, Sabah (North East Borneo), Malaysia during February and March of 1993, 1994 and 1995.

\section{Queen rearing}

For these experiments four colonies of $A$ cerana and four colonies of $A$ koschevnikovi were used each year. We had new colonies each year. The colonies were kept in small movable frame hives $(25 \times 35 \times 42 \mathrm{~cm})$ and contained about $0.5 \mathrm{~kg}$ bees. We removed the queen and examined for the presence of queen cells after 8 days. All queen cells were removed and we made a frame with 12-24 artificial queen cells (diameter $6 \mathrm{~mm}$ ) into which we had grafted young ( $<48 \mathrm{~h}$ ) larvae from worker cells of 'unrelated' donor colonies. The queen cells were arranged in a sequence of alternating species, eg, an artificial queen cell with an A cerana larva was followed by an $A$ koschevnikovi larva which was followed by an $A$ cerana larva and so on. The day of grafting was defined as day 0 . On day 2 we inspected the queen cells for larval acceptance. Cells with accepted larvae had prolonged and drawn out walls (fig 1). The frame was then replaced back into the colony. On day 7 all capped queen cells were removed from the colony. Each queen cell was placed in a small plastic cage and kept in an incubator at $34.5^{\circ} \mathrm{C}\left( \pm 1^{\circ} \mathrm{C}\right)$ and a relative humidity of about $60-70 \%$. On day 8 we added two to three young worker bees (conspecific to the queen cell) from queenless colonies into each cage together with some candy (mixture of icing sugar and $A$ cerana honey) in order to provide the social requirements for the survival of the newly hatched queens. A cerana queens emerged on days 9 and 10. A koschevnikovi queens emerged on days 11 and 12 . Whenever no queen cell was successfully capped the respective series was excluded from the experiment.

\section{Acceptance of alien queen cells and queens}

Queen cells reared in conspecific colonies were used for this experiment. For introduction of virgin queens we attached one ripe queen cell ( 1 or 2 days before emergence) to a comb of a queenless nucleus colony with no larvae younger than 8 days. We carried out daily inspections in the early morning hours and the young queen was marked with paint on the thorax.

\section{Mating flights of A koschevnikovi queens from A cerana colonies}

For observation of mating flights, a glass covered channel was fitted to the hive entrance which was closed in front with a queen excluder (Koeniger et al, 1994). A queen was released as soon as she appeared in the channel by lifting the excluder. After her departure the excluder was closed again. Upon return the queen was found on the excluder and carefully inspected for a mating sign. Then the excluder was temporarily lifted to allow the queen to enter the hive. The colonies were observed from 1400 to 1830 hours (local time $=\mathrm{GMT}+8$ ) during the mating flight experiment period.

\section{RESULTS}

\section{Queen rearing}

A cerana colonies continuously preferred to rear conspecific larvae. After 2 days only 


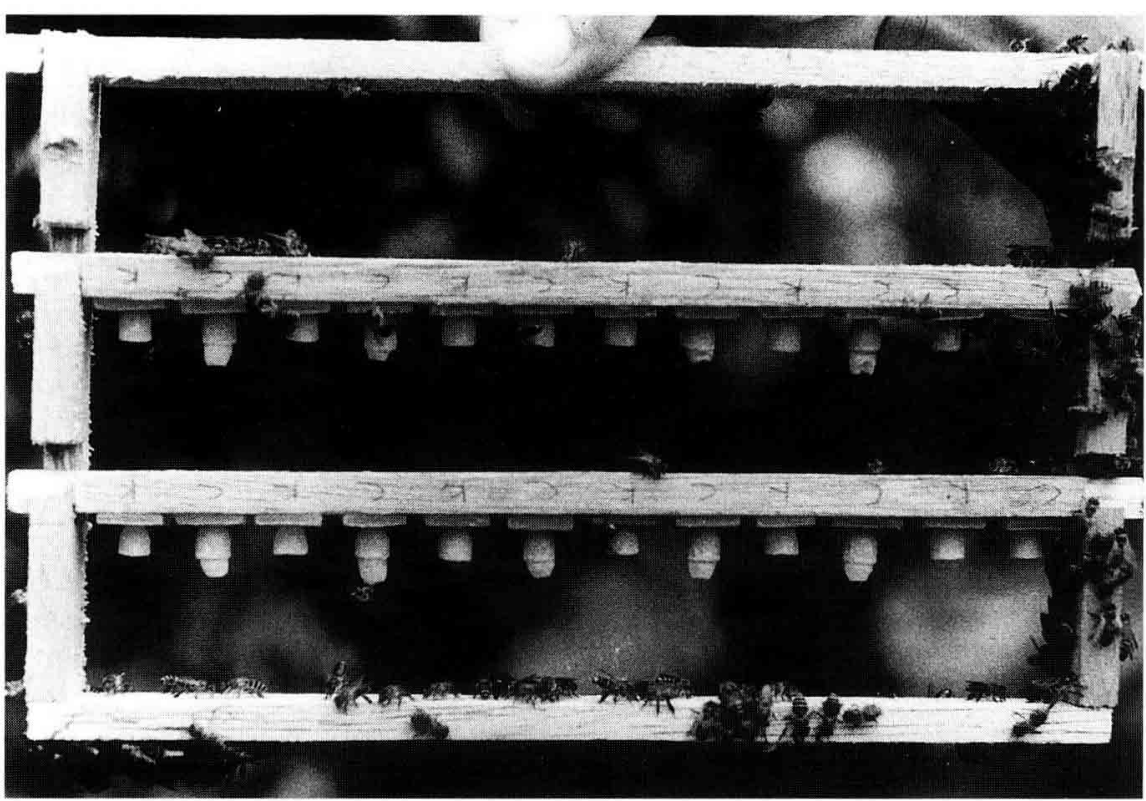

Fig 1. Queen cells from an $A$ cerana colony 2 days after grafting. The workers have drawn out the cell walls and accepted nine artificial queen cells containing $A$ cerana larvae. Twelve cells with $A$ koschevnikovi larvae and three cells with $A$ cerana were not accepted.

32 alien larvae survived as compared to more than twice the number (67) of conspecific brood (fig 1 ). The relation between alien and conspecific queen cells further decreased and as a result four $A$ koschevnikovi queens and 42 A cerana emerged (table I). When queen cells containing larvae of both species were intro-

Table la. Rearing of $A$ koschevnikovi (Ak) and $A$ cerana (Ac) queens in $A$ cerana host colonies.

\begin{tabular}{|c|c|c|c|c|c|c|c|c|}
\hline \multirow[t]{2}{*}{ Date } & \multicolumn{2}{|c|}{ Grafted } & \multicolumn{2}{|c|}{ Accepted } & \multicolumn{2}{|c|}{ Capped } & \multicolumn{2}{|c|}{ Emerged } \\
\hline & Ak & $\mathrm{Ac}$ & Ak & $A C$ & Ak & $A C$ & $A k$ & $A C$ \\
\hline $19 / 2 / 93$ & 12 & 12 & 7 & 8 & 2 & 2 & 2 & 1 \\
\hline $24 / 2 / 93$ & 12 & 12 & 3 & 1 & 4 & 8 & 0 & 4 \\
\hline $3 / 3 / 93$ & 12 & 12 & 11 & 11 & 0 & 4 & 0 & 0 \\
\hline $3 / 2 / 94$ & 12 & 12 & 5 & 7 & 2 & 5 & 0 & 3 \\
\hline $3 / 2 / 95$ & 12 & 12 & 0 & 4 & 0 & 4 & 0 & 4 \\
\hline $6 / 2 / 95$ & 6 & 6 & 1 & 5 & 1 & 5 & 0 & 4 \\
\hline $9 / 2 / 95$ & 12 & 12 & 2 & 10 & 2 & 10 & 2 & 10 \\
\hline 13/2/95 & 12 & 12 & 0 & 12 & 0 & 11 & 0 & 8 \\
\hline $17 / 2 / 95$ & 12 & 12 & 3 & 9 & 0 & 9 & 0 & 8 \\
\hline Total $(\%)$ & $102(100)$ & $102(100)$ & $32(31)$ & $67(66)$ & $11(11)$ & $58(57)$ & $4(4)$ & $42(41)$ \\
\hline
\end{tabular}


duced into $A$ koschevnikovi host colonies a similar trend was observed. A koschevnikovi worker bees also preferred conspecific larvae, but their selection in favor of conspecific queens was less severe. At the end 30 queens of $A$ cerana were reared and 72 conspecific ( $A$ koschevnikovi) queens (fig 2; table II).

\section{Acceptance of alien queens}

In colonies of $A$ koschevnikovi, out of 21 introduced sealed queen cells of $A$ cerana 12 were destroyed and nine young queens were found at the first inspection. The freshly emerged alien queen moved calmly on the comb and did not cause much attention among the $A$ koschevnikovi worker bees. On the first day we rarely saw any antagonistic behavior.
After day 2 (day $0=$ emergence of the queen), however, the $A$ cerana queen was frequently attacked by $A$ koschevnikovi worker bees by grasping her with the mandibles. The queen became motionless and emitted a clearly audible buzzing sound. The surrounding workers then froze their motions and the queen slowly retreated. In this stage, however, several queens had lost some hairs with the rims of their wings already worn off. After day 3, aggressive behavior of $A$ koschevnikovi worker bees became more intense. A cerana queens were surrounded by biting $A$ koschevnikovi worker bees and rarely was a queen able to retreat after a buzzing signal. The $A$ cerana queens were held by workers, balled and heavily injured resulting in death after 5 days (table II). No $A$ cerana queen was able to perform mating flights from the $A$ koschevnikovi host colony.

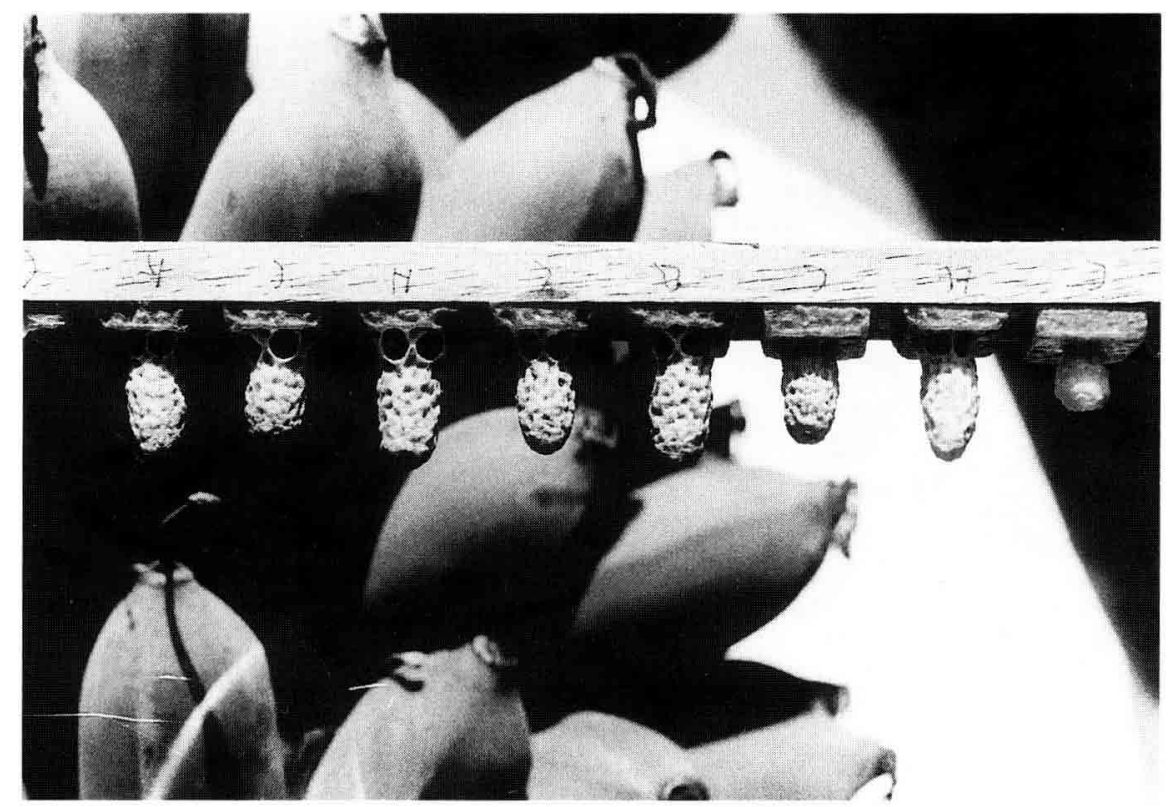

Fig 2. Queen cells from an $A$ koschevnikovi colony 7 days after grafting. Four $A$ koschevnikovi queen cells (from left to right: No 1, No 3, No 5, No 7) are sealed and three $A$ cerana queen cells (No 2, No 4, No 6) are also sealed. One $A$ cerana cell (No 8) was not accepted. 
Table Ib. Rearing of Apis koschevnikovi (Ak) and Apis cerana (Ac) queens in Apis koschevnikovi host colonies.

\begin{tabular}{|c|c|c|c|c|c|c|c|c|}
\hline \multirow[t]{2}{*}{ Date } & \multicolumn{2}{|c|}{ Grafted } & \multicolumn{2}{|c|}{ Accepted } & \multicolumn{2}{|c|}{ Capped } & \multicolumn{2}{|c|}{ Emerged } \\
\hline & $A k$ & $A c$ & $A k$ & $A C$ & $A k$ & $A C$ & $A k$ & $A c$ \\
\hline $19 / 1 / 93$ & 6 & 6 & 3 & 4 & 3 & 4 & 3 & 4 \\
\hline $21 / 1 / 93$ & 6 & 6 & 4 & 3 & 3 & 3 & 1 & 0 \\
\hline $29 / 1 / 93$ & 12 & 12 & 10 & 9 & 8 & 7 & 5 & 4 \\
\hline $27 / 2 / 93$ & 10 & 10 & 7 & 6 & 5 & 2 & 5 & 1 \\
\hline $4 / 3 / 93$ & 10 & 10 & 5 & 5 & 2 & 2 & 2 & 1 \\
\hline $4 / 2 / 94$ & 12 & 12 & 11 & 8 & 10 & 7 & 7 & 7 \\
\hline 9/2/94 & 12 & 12 & 10 & 5 & 9 & 5 & 8 & 3 \\
\hline $14 / 2 / 94$ & 12 & 12 & 9 & 5 & 7 & 4 & 3 & 1 \\
\hline $25 / 2 / 94$ & 12 & 12 & 8 & 4 & 8 & 4 & 5 & 2 \\
\hline $15 / 2 / 95$ & 12 & 12 & 12 & 7 & 8 & 4 & 8 & 4 \\
\hline $14 / 2 / 95$ & 12 & 12 & 7 & 4 & 7 & 4 & 6 & 2 \\
\hline 20/2/95 & 12 & 12 & 12 & 12 & 12 & 11 & 10 & 0 \\
\hline 26/2/95 & 12 & 12 & 12 & 11 & 12 & 11 & 9 & 1 \\
\hline Total (\%) & $140(100)$ & $140(100)$ & $110(79)$ & $83(59)$ & $94(67)$ & $68(49)$ & $72(51)$ & $30(21)$ \\
\hline
\end{tabular}

Table II. Acceptance of alien queen cells and queens.

Introduced queen cells (day 0 )

Destroyed during day 1-2

Queen lost during day 3-5

Lost during mating

Oviposition/transformation of colony

$\begin{array}{rr}18 & 21 \\ 8 & 12 \\ 6 & 9 \\ 1 & 0 \\ 3 & 0\end{array}$

A cerana colonies destroyed nearly $50 \%$ ( $n=8$ ) of the alien queen cells before or during emergence. Some $A$ cerana colonies ( $n=6$ ) killed the $A$ koschevnikovi queens during the first period. The behavior of $A$ cerana host bees was similar as described above for A koschevnikovi. The A cerana workers attacked the young alien queen and the aggressions increased as the queens aged in the colonies. The queens were then balled, injured and expelled. In four $A$ cerana colonies, however, the aggressive behavior of the A cerana workers towards the A koschevnikovi queen decreased after day
2. The queen moved somewhat restlessly over the combs and whenever she was encountered by antennating or grooming workers, a short buzzing of the queen would ward off each worker bee. These queens performed a full mating flight activity during which one $A$ koschevnikovi queen got lost (did not return). Three queens successfully mated and started laying eggs 4 days after the last mating flight (table II). The eggs hatched and the A cerana workers successfully reared the $A$ koschevnikovi larvae. With the newly hatching bees the originally 'pure' $A$ cerana worker bee population 
became interspecifically mixed. We were not able to systematically observe this transition until the $A$ cerana workers were completely replaced by $A$ koschevnikovi worker bees. Interspecific aggressions at the hive entrance or fights between $A$ cerana and A koschevnikovi worker bees during colony inspection were not observed.

\section{Mating flights of A koschevnikovi queens from A cerana and $\mathrm{A}$ koschevnikovi colonies}

Four A koschevnikovi virgin queens introduced into A cerana colonies performed 16 flights which include three flights from which the queen came back with a mating sign. For comparison, we observed three A koschevnikovi virgin queens which started from conspecific colonies. The queen flights occurred between 1700 and 1815 hours in both types of host colonies (table IV). During the initial period (1700 to 1745 hours) the flight duration was average $2.6 \pm 1.9 \mathrm{~min}$. Successful mating flights (flights from which the queen returned with mating sign) occurred in a relatively short period of 30 min from 1746 till 1815 hours and flight duration was $19.1 \pm 4.9 \mathrm{~min}$. The median time for the total flight activity of the queens from A cerana colonies was 1748 hours and the median for flights from $A$ koschevnikovi colonies was 1743 hours. The period of total flight activity as well as the period of successful mating flights did not differ significantly between queens starting from alien and conspecific colonies ( $P=0.83$, Wilcoxon Rank Sum W test).

\section{DISCUSSION}

Several crossfostering experiments between $A$ mellifera and $A$ cerana have been conducted. Many of these experiments were outlined or discussed by Ruttner (1988). Alien uncapped brood (eggs and larvae) was cannibalized or removed (Dhaliwal and Atwal, 1970). Capped worker brood of $A$ cerana was accepted and hatched in $A$ mellifera colonies. The hatched $A$ cerana workers were expelled from an $A$ mellifera colony (Sakagami, 1959). Young A mellifera worker bees were accepted in $A$ cerana colonies and participated in social duties. When returning from their first orientation flights, however, the $A$ mellifera workers were attacked by $A$ cerana guard bees (Ruttner, 1988). Rearing queens from $A$ cerana larvae in $A$ mellifera colonies was tried with little or no success. In the course of numerous grafting experiments with artificial queen cells, eight $A$ cerana larvae were accepted and four of these cells were capped. No queen, however, emerged and an inspection

Table III. Mating flights of seven virgin A koschevnikovi queens from four alien and three conspecific colonies.

\begin{tabular}{|c|c|c|c|c|c|c|c|}
\hline Colony & $\begin{array}{c}1700-1715 \\
\text { hours }\end{array}$ & $\begin{array}{c}1716-1730 \\
\text { hours }\end{array}$ & $\begin{array}{c}1731-1745 \\
\text { hours }\end{array}$ & $\begin{array}{c}1746-1800 \\
\text { hours }\end{array}$ & $\begin{array}{c}1801-1815 \\
\text { hours }\end{array}$ & $\begin{array}{c}1816-1830 \\
\text { hours }\end{array}$ & Total \\
\hline A cerana & 0 & 2 & 6 & $4(1)$ & $4(2)$ & 0 & 16 \\
\hline A koschevnikovi & 1 & 2 & 4 & $6(2)$ & $2(1)$ & 0 & 15 \\
\hline Total & 1 & 4 & 10 & $10(3)$ & $6(3)$ & 0 & 31 \\
\hline
\end{tabular}

In parentheses: number of flights from which the queen returned with mating sign. 
of the cells after the due time resulted in very big larvae without any sign of pupation (Ruttner, 1988). Inoue (1962) grafted 100 larvae of $A$ cerana japonica into queenless and broodless $A$ mellifera colonies, and got only three queens, which were not accepted by the $A$ mellifera colonies in which they emerged. Recently, Pothichot et al (1993) grafted alien larvae in artificial queen cells of $A$ cerana and $A$ mellifera colonies in Thailand without any success. All alien larvae were rejected whereas conspecific larvae were reared in a high percentage.

In this study we grafted queen cells with conspecific and alien larvae simultaneously into either $A$ cerana or $A$ koschevnikovi host colonies. This technique was employed to give larvae equal chances of being accepted and reared. As expected there was a strong tendency for preference of conspecific larvae in both species. This tendency, however, was stronger in $A$ cerana colonies which reared significantly fewer alien queens than $A$ koschevnikovi colonies $\left(P<0.1, \mathrm{Chi}^{2}=7.24\right)$. As regards the acceptance of a young alien queen, $A$ koschevnikovi colonies were more selective. All $A$ cerana queens were eliminated by the $A$ koschevnikovi worker bees.

The reaction of the queen to aggression of alien workers was characterized by a buzzing sound. With $A$ mellifera, the virgin queen emits piping sounds which results in a sudden freezing of the worker's movements (Hamman, 1957; Michelsen et al, 1986). We observed a freezing reaction of the A koschevnikovi workers to the A cerana queen buzzing and a similar reaction of $A$ cerana workers to the $A$ koschevnikovi queen. Apparently, the interspecific acoustic communication between queen and workers was successful. This observation corroborates the findings of Otis et al (1995), indicating that the queen piping of $A$ cerana and $A$ koschevnikovi was similar but significantly different to $A$ mellifera.

The aggressive behavior, however, towards the alien queen increased gradu- ally with the age of the queen, and at day 3 or 4 (after emergence) the queen was balled, mutilated and finally expelled from the colony. In A mellifera the young queen starts pheromone synthesis after emergence and an increasing amount of mandibular pheromones (specially 9-keto-(E)-2decenoic acid) is produced until a physiological level is reached at the time of mating flight (Slessor et al, 1990). We assume that this pheromone synthesis happens similarly in young queens of $A$ cerana and $A$ koschevnikovi. The observed worker aggressions seemed to increase parallel to an increase of queen pheromones.

According to Plettner et al (1996) the blend of the queen's mandibular pheromones is distinctly different among the several species of the genus Apis (data on mandible gland pheromones of $A$ koschevnikovi have yet to be established). Therefore, one reason for the host worker bees' aggression might be due to the increasingly wrong blend of pheromones emitted by the introduced alien queen.

The reactions of $A$ cerana host colonies to young $A$ koschevnikovi queens were not consistent. In six colonies the young $A$ koschevnikovi queens were attacked and killed. In four colonies, however, the initial antagonistic behavior of the $A$ cerana workers ceased allowing the development of the A koschevnikovi queen to sexual maturity and performance of successful mating flights. The $A$ koschevnikovi queens then started oviposition and the eggs hatched and were successfully reared by the $A$ cerana host workers. This observation was rather unexpected since $A$ cerana colonies rejected nearly all $A$ koschevnikovi queen cells. In the latter experiments, the bees had the choice between alien and conspecific larvae, whereas after accepting the $A$ koschevnikovi queen only $A$ koschevnikovi eggs and worker larvae were available. Further, we cannot exclude that the criteria for acceptance are different for worker brood. 
Eventually more and more $A$ koschevnikovi workers emerged and the $A$ cerana workers were replaced. Though the biological situation of this experiment is not typical for Apis, it has some similarities with a common phenomenon in other social Hymenoptera, bumble bees, ants or social wasps where an alien queen starts reproduction and converts the host colony to her own species (Wilson, 1971). In nearly all these cases a close systematic relatedness between both species, the queen's and the species of host colony, seems to be a functional requirement.

The mating flight data of $A$ koschevnikovi queens flying from conspecific or A cerana colonies did not reveal systematic differences. Therefore we conclude that the queens followed their own internal clock. Similarly, crossfostered drones of $A$ koschevnikovi and $A$ cerana flew at their species specific mating time (Koeniger et al, 1994). Generally, the time of the mating flight seems to depend on the individual's (drone or queen) internal clock in the genus Apis.

Thus the reproductive isolation mechanism of sympatric Apis species is based on individual behavior of the sexual castes (Koeniger et al, 1988, 1996).

Our experiments did not reveal a general and uniform, species-specific pattern: $A$ cerana colonies rejected more $A$ koschevnikovi larvae grafted in queen cells but accepted more A koschevnikovi queens. Nevertheless the interspecific transfer and acceptance of queen cells and queens between $A$ cerana and $A$ koschevnikovi was more successful than the exchange between $A$ mellifera and $A$ cerana. Assuming that a closer relationship between an alien queen and a host colony favors acceptance, our results were in line with the current taxonomy of the cavity-dwelling Apis species, which gives $A$ cerana and $A$ koschevnikovi positions close to each other whereas $A$ mellifera is more distant to both Asian species (Rinderer et al, 1989; Ruttner et al, 1989;
Koeniger and Koeniger, 1991; Fuchs et al, 1996). It will be of a great interest to extend crossfostering experiments to Apis nuluensis, the recently described, third cavity-dwelling species of Borneo (Tingek et al, 1996).

\section{ACKNOWLEDGMENTS}

We acknowledge support and assistance of JA Yaacob, director of Agriculture Sabah, PP Kee, assistant director (research branch), D Simin, officer in charge ARS Tenom. S Sheppard (WSU, Pullman, USA) and S Fuchs (IfB, Oberursel) gave valuable advice and contributed to the improvement of earlier versions of the manuscript.

Résumé - Élevage et acceptation interspécifiques de reines entre Apis cerana Fabricius, 1793 et Apis koschevnikovi Buttel-Reepen, 1906. L'acceptation interspécifique réciproque du couvain de mâles et de mâles adultes d'A cerana et d'A koschevnikovi pose la question de savoir s'il en est de même pour les larves de reines et les reines adultes de ces deux espèces. Dans des colonies orphelines d'A cerana et d'A koschevnikovion a introduit des cellules royales artificielles renfermant de jeunes larves soit de la même espèce, soit de l'autres espèce. Les deux espèces d'abeilles mellifères ont préféré élever les larves de leur propre espèce. Les colonies d'A cerana, en particulier, ont constamment choisi les larves de leur espèce (fig 1): seules quatre reines d' $A$ koschevnikovi ont été élevées, alors que 42 reines d'A cerana ont émergé pendant la même période (tableau la). La sélection par les colonies d'A koschevnikovi a été moins sévère (fig 2) : 30 reines d' $A$ cerana et 72 reines d'A koschevnikovi ont été élevées (tableau lb). Pour tester l'acceptation des reines, des cellules royales mûres ( 1 à 2 j avant l'émergence) ont été introduites dans des colonies orphelines de l'autre espèce et - à condition que les ouvrières n'aient pas détruit la cellule royale - la jeune reine 
a émergé dans la colonie étrangère. Sur 18 cellules royales d' $A$ cerana introduites dans des colonies d'A koschevnikovi, nous avons trouvé dix jeunes reines d'A cerana (huit cellules royales ont été détruites). Les reines étrangères fraîchement écloses n'ont pas beaucoup attiré l'attention des ouvrières le premier jour mais, plus tard, elles ont été constamment entourées par des ouvrières qui les mordaient et elles sont mortes par emballement (tableau II). Les colonies d'A cerana ont détruit à un stade précoce presque $50 \%$ des cellules royales étrangères. Dans six colonies d'A cerana, les reines d'A koschevnikovi ont été tuées au cours des premiers jours. Mais dans quatre colonies d'A cerana le comportement agressif des ouvrières envers la reine étrangère a diminué au bout de deux jours. Une reine d'A koschevnikovi n'est pas rentrée de son vol de fécondation. Trois reines se sont accouplées et ont commencé à pondre quatre jours après le dernier vol de fécondation (tableau II). Les œufs ont éclos et les ouvrières d'A cerana ont élevé avec succès le couvain d'A koschevnikovi. Les ouvrières d'A koschevnikovi récemment écloses ont rendu la population d'ouvrières de la colonie d'A cerana graduellement hétérospécifique jusqu'à ce que les ouvrières d'A cerana soient toutes remplacées par des ouvrières d'A koschevnikovi. Les vols de fécondation des reines d'A koschevnikovi ont eu lieu entre 17 h et $18 \mathrm{~h} 15$ (tableau III). L'heure moyenne des vols de reines des colonies d'A cerana s'est située à 17 h 48 , celle des reines des colonies d'A koschevnikovi à 17 h 43. II n'y a pas eu de différence significative entre les reines s'envolant de colonies étrangères et celles s'envolant de colonies de la même espèce en ce qui concerne l'activité totale de vol et la durée des vols de fécondation réussis $(p=0,83$, Wilcoxon Rank Sum W test).

\section{Apis cerana / Apis koschevnikovi / rela- tion interspécifique / acceptation reine / élevage reine / reproduction}

Zusammenfassung - Interspezifische Aufzucht und Annahme von Königinnen zwischen den Arten Apis cerana Fabricius, 1793 und Apis koschevnikovi Buttel-Reepen ,1906. Künstliche Königinnenzellen mit jungen Arbeiterinnenlarven der eigenen und der fremden Art wurden weisellosen Völkern von $A$ cerana bzw. A koschevnikovi angeboten. Beide Honigbienenarten zogen bevorzugt Larven der eigenen Art auf. Insbesondere wählten A cerana-Völker deutlich mehr konspezifische Larven (Abb 1); im Ergebnis wurden nur 4 Königinnen von $A$ koschevnikovi aufgezogen, während in der gleichen Zeit 42 A cerana-Königinnen schlüptten (Tabelle I a). Die gegen fremde Königinnen gerichtete Wahl von $A$ koschevnikovi-Völkern war weniger streng ( $\mathrm{Abb} 2$ ). Bis zum Ende dieses Experiments wurden 30 Königinnen von A cerana und 72 der konspezifischen A koschevnikovi-Königinnen aufgezogen (Tabelle I b). Um die Annahme fremder Königinnen zu untersuchen, wurden reife Königinnenzellen in weisellose Völker eingesetzt. Falls die Zellen nicht von den Arbeiterinnen zerstört wurden, schlüpften die jungen Königinnen in den artfremden Völkern. Aus den 18 in A koschevnikovi-Völker eingebrachten $A$ cerana-Königinnenzellen fanden wir 10 junge $A$ cerana-Königinnen; 8 der Zellen waren zerstört worden. Am ersten Tag wurden die frischgeschlüpften Königinnen der fremden Art von den A koschevnikovi-Königinnen kaum beachtet. Später waren diese Königinnen jedoch beständig von Arbeiterinnen umgeben, die sie bissen und einknäulten bis diese starben. Die A koschevnikovi-Völker wiesen damit alle eingeführten artfremden Königinnen zurück (Tabelle II). Die A cerana-Völker zerstörten ebenfalls nahezu $50 \%$ der Königinnenzellen bereits in einem frühen Stadium. In 6 A cerana-Völkern wurden die $A$ koschevnikovi-Königinnen während der ersten Tage getötet. In 4 der A cerana-Völker liess das aggressive Verhalten der Arbeiterinnen gegen die A koschevnikovi Königinnen 
dagegen nach 2 Tagen nach. Eine der A koschevnikovi-Königinnen kehrte von ihrem Paarungsflug nicht zurück. Drei der Königinnen paarten sich erfolgreich und begannen vier Tage nach dem letzten Paarungsflug mit der Eiablage (Tabelle II). Nach dem Schlupf der Maden wurde die A koschevnikovi-Brut erfolgreich von den A cerana-Arbeiterinnen aufgezogen. Nach dem Schlupf der A koschevnikovi-Arbeiterinnen war die Arbeiterinnenpopulation zunächst heterospezifisch zusammengesetzt bis alle $A$ cerana-Arbeiterinnen durch $A$ koschevnikovi-Arbeiterinnen ersetzt waren (Tabelle II). Die Paarungsflüge der A koschevnikovi-Königinnen fanden zwischen 17.00 und 18.15 statt (Tabelle III). Der Median der Ausflugzeiten von Königinnen aus $A$ cerana-Völkern war 17.48 , der aus $A$ koschevnikovi-Völkern 17.43. Zwischen den aus Völkern der eigenen oder der fremden Art ausfliegenden Königinnen bestanden keine signifikanten Unterschiede in der gesamten Flugaktivität oder des Zeitraums der erfolgreichen Paarungsflüge ( $P=3$ D0.83, Wilcoxon Rangsummen Test).

\section{Apis cerana / Apis koschevnikovi/Inter- spezifische Beziehung / Königin / Fort- pflanzung}

\section{REFERENCES}

Dhaliwal GS, Atwal AS (1970) Interspecific relations between Apis cerana indica and Apis melliera. J Apic Res 9, 53-59

Fuchs S, Koeniger N, Tingek S (1996) The morphometric position of Apis nuluensis (Tingek, Koeniger and Koeniger 1996) within the the cavity-nesting honey bee species. Apidologie 27, 397-405

Hamman E (1957) Wer hat die Initiative bei den Ausflügen der Jungkönigin, die Königin oder die Arbeitsbienen? Insectes Soc 4, 91-106

Inoue A (1962) Preliminary report on rearing of Japanese honey bee queens in colonies of the European honey bee. Bee Science 3, 10

Koeniger G, Koeniger N, Tingek S (1994) Crossfostered drones of Apis cerana (Fabricius 1793) and Apis koschevnikovi (Buttel-Reepen 1906) fly at their species specific mating times. Insectes Soc 41, 73 78

Koeniger N, Koeniger G (1991) An evolutionary approach to mating behaviour and drone copulatory organs in Apis. Apidologie 22, 581-590

Koeniger N, Koeniger G, Gries M, Tingek S, Kelitu A (1996) Reproductive isolation of Apis nuluensis (Tingek, Koeniger and Koeniger, 1996) by speciesspecific mating time. Apidologie 27, 353-360

Koeniger N, Koeniger G, Tingek S, Mardan M, Rinderer TE (1988) Reproductive isolation by different time of drone flight between Apis cerana Fabricius, 1793 and Apis vechti (Maa, 1953). Apidologie 19, 103-106

Michelsen A, Kirchner WH, Andersen BB, Lindauer M (1986) The tooting and quacking vibration signals of the honey bee queens: a quantitative analysis. J Comp Pysiol A 158, 605-611

Otis GW, Patton K, Tingek S (1995) Piping by queens of Apis cerana (Fabricius 1793) and Apis koschevnikovi (Buttel-Reepen 1906). Apidologie 26, 61-65

Pothichot S, Wongsiri S, Dietz A (1993) Attempts in queen rearing of Apis cerana larvae in Apis mellifera colonies and Apis mellifera larvae in Apis cerana colonies. In: Asian Apiculture. Proc 1st int Conf Asian Honey Bees and Bee Mites. Bangkok. Thailand, Wicwas Press, Cheshire, CT, USA, 112-117

Plettner E, Otis GW, Wimalaratne PDC. Winston ML, Slessor KN, Pankiw T, Punchihewa PWK (1996) Species- and caste-determined mandibular gland signals in honey bees (Apis). $J$ Chem Ecol (in press)

Rinderer TE, Koeniger N, Tingek S, Mardan M, Koeniger $G$ (1989) A morphological comparison of the cavity dwelling honey bees of Borneo Apis koschevnikovi (Buttel-Reepen 1906) and Apis cerana (Fabricius 1793). Apidologie 20, 405-411

Ruttner F (1988) Biogeography and Taxonomy of Honeybees. Springer Verlag, Berlin, 284

Ruttner F, Kauhausen D, Koeniger N (1989) Position of the red honey bee Apis koschevnikovi (ButtelReepen 1906), within the genus Apis. Apidologie 20, 395-404

Sakagami SF (1959) Some interspecific relations between Japanese and European honey bees. $J$ Anim Ecol 28, 51-68

Slessor KN, Kaminski LA, King GGS, Winston ML (1990) Semiochemicals of the honey bee queen mandibular glands. J Chem Ecol 16, 851-860

Tingek S, Koeniger G, Koeniger N (1996) Description of a new cavity nesting species of Apis (Apis nuluensis) from Sabah. Borneo with notes on its occurrence and reproductive biology (Hymenoptera: Apoidea: Apini) Senckenbergiana Biol 76, 115-119

Tingek S, Mardan M, Rinderer TE, Koeniger N, Koeniger $G$ (1988) Rediscovery of Apis vechti (Maa1953): the Saban honey bee. Apidologie 19, 97-102

Wilson EO (1971) The Insect Societies. Harvard University Press, Cambridge, MS, 548 